\title{
Purification and Properties of Glutamate Synthase and Glutamate Dehydrogenase from Bacillus megaterium
}

\author{
By ILKKA A. HEMMILÄ and PEKKA I. MÄNTSÄLÄ \\ Department of Biochemistry, University of Turku, 20500 Turku 50, Finland
}

(Received 15 September 1977)

\begin{abstract}
Bacillus megaterium N.C.T.C. no. 10342 exhibits glutamate synthase (EC 2.6.1.53) and glutamate dehydrogenase (EC 1.4.1.4) activities. Concentrations of glutamate synthase were high when the bacteria were grown on $3 \mathrm{mM}-\mathrm{NH}_{4} \mathrm{Cl}$ and low when they were grown on $100 \mathrm{mM}-\mathrm{NH}_{4} \mathrm{Cl}$, whereas glutamate dehydrogenase concentrations. were higher when the bacteria were grown on $100 \mathrm{~mm}-\mathrm{NH}_{4} \mathrm{Cl}$ than on $3 \mathrm{mM}-\mathrm{NH}_{4} \mathrm{Cl}$. Glutamate synthase and glutamate dehydrogenase were purified to homogeneity from $B$. megaterium grown in $10 \mathrm{~mm}$-glucose $/ 10 \mathrm{~mm}-\mathrm{NH}_{4} \mathrm{Cl}$. The purified enzymes had mol.wts. 840000 and 270000 for glutamate synthase and glutamate dehydrogenase respectively. The $K_{\mathrm{m}}$ values for substrates with NADPH and coenzyme were (glutamate synthase activity shown first) $9 \mu \mathrm{M}$ and $360 \mu \mathrm{M}$ for 2-oxoglutarate, $7.1 \mu \mathrm{M}$ and $8.7 \mu \mathrm{M}$ for NA.DPH, and $0.2 \mathrm{~mm}$ for glutamine and $22 \mathrm{mM}$ for $\mathrm{NH}_{4} \mathrm{Cl}$, similar values to those of enzymes from Escherichia coli. Glutamate synthase contained $\mathrm{NH}_{3}$-dependent activity (different from authentic glutamate dehydrogenase), which was enhanced 4-fold during treatment at $\mathrm{pH}$ 4.6. $\mathrm{NH}_{3}$-dependent activity was generally about $2 \%$ of the glutamine-dependent activity. Amidination of glutamate synthase by the bi-functional cross-linking reagent dimethyl suberimidate inactivated glutamine-dependent glutamate synthase activity, but increased $\mathrm{NH}_{3}$-dependent activity. A cross-linked structure of mol.wt. approx. 200000 was the main product formed.
\end{abstract}

In bacteria the biosynthesis of glutamate from $\mathrm{NH}_{3}$ is catalysed by glutamate dehydrogenase and by the coupled functioning of glutamine synthetase and glutamate synthase. In bacilli glutamate is utilized for both growth and sporulation and thus the synthesis of amino acid cannot be readily explained, especially because bacilli are generally thought to lack glutamate dehydrogenase activity (Phibbs \& Bernlohr, 1971). Meers et al. (1971) and Meers \& Pedersen (1971) concluded that glutamate dehydrogenase is used to assimilate $\mathrm{NH}_{3}$ under the growth conditions of excess of $\mathrm{NH}_{3}$. The addition of glutamate to a carbon-limited chemostat culture results in direct deamination of the amino acid, thus preventing an excessive increase in the glutamate pool. Extremely low glutamate dehydrogenase activities were detected when glutamate was the only source of carbon and nitrogen (Phibbs \& Bernlohr, 1971). Elmerich \& Aubert (1971) reported that coupled reactions of glutamine synthetase and glutamate synthase represent the major pathway of glutamate synthesis in Bacillus megaterium.

Glutamate dehydrogenase has been purified 55 -fold from Bacillus licheniformis (Phibbs \& Bernlohr, 1971) and 250-300-fold from a thermophilic bacillus (Epstein \& Grossowics, 1975). Glutamate synthase

Abbreviations used: SDS, sodium dodecyl sulphate; Hepes, 4-(2-hydroxyethyl)-1-piperazine-ethanesulphonic acid. has been purified about 20 -fold from $B$. megaterium (Elmerich \& Aubert, 1971). The highly purified glutamate dehydrogenase from a thermophilic bacillus has a molecular weight $\left(2 \times 10^{6}\right)$ and $K_{\mathrm{m}}$ value quite different from those of the other bacterial sources.

Our data provide evidence that $B$. megaterium N.C.T.C. no. 10342 exhibits both glutamate dehydrogenase and glutamate synthase activities, and that the concentrations of the enzymes are regulated by the glucose $/ \mathrm{NH}_{3}$ ratio. Purified glutamate synthase and glutamate dehydrogenase are similar in enzymic and molecular properties to glutamate synthase and glutamate dehydrogenase from other bacterial sources.

\section{Materials and Methods}

\section{Reagents}

$\mathrm{L}-\left[\mathrm{U}-{ }^{14} \mathrm{C}\right]$ Glutamine (sp. radioactivity $38 \mathrm{mCi} /$ $\mathrm{mmol}$ ) and iodo $\left[1-{ }^{14} \mathrm{C}\right]$ acetamide (sp. radioactivity $3.6 \mathrm{mCi} / \mathrm{mmol}$ ) were obtained from The Radiochemical Centre, Amersham, Bucks., U.K. Octanedinitrile was purchased from Aldrich Chemical Co., Beerse, Belgium. Ultrogel AcA 22 was a product of Industrie Biologique Française and was from LKBProdukter A.B., Stockholm, Sweden. $\beta$-Galactosidase, alcohol dehydrogenase, glyceraldehyde 3- 
phosphate dehydrogenase and bovine serum albumin were from Boehringer, Mannheim, Germany. Glutamate synthase from Escherichia coli was purified as previously described (Mäntsälä \& Zalkin, 1976a).

\section{Bacterial strain and cultivation}

The bacterial strain used for the enzyme purification was B. megaterium N.C.T.C. no. 10342 . The freeze-dried cells were cultured first in the Micro Inoculum Broth (Difco Laboratories, Detroit, MI, U.S.A.) medium, then in Micro Inoculum Broth $(0.5 \%) / 10 \mathrm{~mm}$-glucose / $10 \mathrm{~mm}-\mathrm{NH}_{3}$ medium and finally in $10 \mathrm{~mm}$-glucose $/ 10 \mathrm{~mm}-\mathrm{NH}_{3}$ medium. If the inocula were stored at $8^{\circ} \mathrm{C}$ for longer than 2 weeks there was no longer any growth in the minimal medium. The main cultures were grown aerobically at $35^{\circ} \mathrm{C}$ in a glucose $/ \mathrm{NH}_{3}$ minimal medium (Miller \& Stadtman, 1972). The cells were harvested by centrifugation for $15 \mathrm{~min}$ at $7000 \mathrm{~g}$ in the late-exponential phase if not otherwise stated. For the extraction of proteins $280 \mathrm{~g}$ of cells was disrupted in $10 \mathrm{~mm}-$ potassium phosphate / $10 \mathrm{~mm}-2$ - mercaptoethanol/ $1 \mathrm{~mm}$-EDTA buffer, pH 7.2 (buffer A) $(3 \mathrm{ml} / \mathrm{g}$ of cell paste), by French-press treatment as described by Mäntsälä \& Zalkin (1976a). The suspension was finally centrifuged at $30000 \mathrm{~g}$ for $1 \mathrm{~h}$ at $4^{\circ} \mathrm{C}$.

\section{Enzyme assays}

Glutamine- and $\mathrm{NH}_{3}$-dependent glutamine synthase activities were assayed as previously described (Miller \& Stadtman, 1972; Mäntsälä \& Zalkin, 1976a). The glutamate dehydrogenase assay was as described by Mäntsälä \& Zalkin (1976b), except that $4 \mathrm{~mm}$-2-oxoglutarate was used. In each case 1 unit of activity corresponds to the amount of enzyme catalysing the utilization of $1 \mu \mathrm{mol}$ of $\mathrm{NADPH} / \mathrm{min}$ at $25^{\circ} \mathrm{C}$. Glutaminase activity was determined by the method of Curthoys \& Weiss (1974).

\section{Electrophoresis}

Discontinuous polyacrylamide-gel electrophoresis at $\mathrm{pH} 8.5$ was performed as described by Baker $e t$ al. (1972) and polyacrylamide-gel electrophoresis in the presence of $0.1 \%$ SDS at $\mathrm{pH} 7.1$ by the procedure of Shapiro et al. (1967), as modified by Weber \& Osborn (1969).

\section{Molecular-weight determinations}

Molecular-weight estimations were performed as described by Martin \& Ames (1961) by using sucrosedensity-gradient centrifugation. Sucrose gradients from 5 to $20 \%(\mathrm{w} / \mathrm{v})$ were used. Samples in $0.2 \mathrm{ml}$ of buffer B (buffer A containing 2 mM-2-oxoglutarate and
$100 \mathrm{~mm}-\mathrm{KCl}$ ) were layered on $19.8 \mathrm{ml}$ gradients and centrifuged in an MSE Super Speed 50 ultracentrifuge at $100000 \mathrm{~g}$ for $10 \mathrm{~h}$. E. coli $\beta$-galactosidase (mol.wt. 540000) and yeast alcohol dehydrogenase (mol.wt. 141000 ) served as the reference standards. SDS/ polyacrylamide-gel electrophoresis was used to determine subunit molecular weights. $\beta$-Galactosidase (subunit mol.wt. 135000), bovine serum albumin (mol.wt. 67000), catalase (subunit mol.wt. 60000) and glyceraldehyde 3-phosphate dehydrogenase (subunit mol.wt. 37000) were used as the standards.

\section{Incorporation of $\left[{ }^{14} \mathrm{C}\right]$ carbamoylmethyl}

Reaction mixtures contained glutamate synthase (0.64 mg), 20mm-Hepes (potassium salt, pH7.2) and $0.180 \mathrm{~mm}$-iodo $\left[1{ }^{-14} \mathrm{C}\right]$ acetamide in a final volume of $0.3 \mathrm{ml}$. After incubation for $30 \mathrm{~min}$ at $25^{\circ} \mathrm{C}$ the mixture was passed through a column $(1 \mathrm{~cm} \times 20 \mathrm{~cm})$ of Sephadex G-25. The column was eluted with $20 \mathrm{~mm}$-Hepes and the enzyme fractions were pooled and dialysed against $500 \mathrm{vol}$. of the same buffer solution and counted for radioactivity as described by Nagano et al. (1970).

\section{Preparation of apo-(glutamate synthase)}

Glutamate synthase was precipitated with $0.2 \mathrm{M}$ potassium acetate, $\mathrm{pH} 4.6$, as described by Mäntsälä $\&$ Zalkin $(1976 a)$. After incubation at $4^{\circ} \mathrm{C}$ for $3 \mathrm{~h}$ the suspension was returned to neutral $\mathrm{pH}$ by addition of $1 \mathrm{M}$-Tris $/ \mathrm{HCl}$ (pH8.5). The precipitate was isolated by centrifugation for $15 \mathrm{~min}$ at $5000 \mathrm{~g}$ and suspended in $20 \mathrm{~mm}$-Hepes (potassium salt) buffer, pH7.2. The concentration of the released flavin was determined as described by Burch et al. (1948).

\section{Cross-linking studies}

Amidination of glutamate synthase was carried out in $0.2 \mathrm{M}$-triethanolamine hydrochloride ( $\mathrm{pH} 8.5$ ) as described by Davies \& Stark (1970). Dimethyl suberimidate was prepared by the method of McElvain \& Schroeder (1949). Dimethyl suberimidate and glutamate synthase were mixed to give $1.2 \mathrm{mg}$ of protein $/ \mathrm{ml}$ and $3 \mathrm{mg}$ of suberimidate $/ \mathrm{ml}$ in a volume of $150 \mu \mathrm{l}$. Samples $(30 \mu \mathrm{l})$ were taken at intervals of $30 \mathrm{~min}$, denatured (Mäntsälä \& Zalkin, 1976a) and electrophoresed as described above in the presence of $0.1 \%$ SDS. The gels $(12 \mathrm{~cm} \times 0.5 \mathrm{~cm})$ contained $3 \%(\mathrm{w} / \mathrm{v})$ acrylamide.

Protein was determined by the method of Lowry et al. (1951) with bovine serum albumin as standard. Amino acid analyses were carried out in a PerkinElmer KLA-5 amino acid analyser. 


\section{Results}

\section{Growth experiments}

There was no significant difference in the concentrations of glutamate synthase when glutamate or lysine served as the nitrogen source (Table 1). In the presence of $3 \mathrm{mM}-\mathrm{NH}_{4} \mathrm{Cl}$ the cultures ceased growth at a Klett reading of 111 , with filter no. 62 . However, the concentrations of glutamate synthase were higher than in the $100 \mathrm{~mm}-\mathrm{NH}_{4} \mathrm{Cl}$ medium, whereas glutamate dehydrogenase concentrations were high in the $\mathrm{NH}_{3}$-rich medium.

\section{Enzyme purifications}

Nucleic acids were removed from the crude extract by the slow addition of $1 \%$ streptomycin sulphate $(10 \mathrm{ml} \mathrm{of} 10 \%$ streptomycin sulphate $/ 100 \mathrm{ml}$ of crude extract). The supernatant was treated with a saturated solution of $\left(\mathrm{NH}_{4}\right)_{2} \mathrm{SO}_{4}$ adjusted with $\mathrm{KOH}$ to $\mathrm{pH}$ 7.2. Proteins precipitated between 33 and $53 \%$ saturation were dissolved in $92 \mathrm{ml}$ of buffer B and heated at $62^{\circ} \mathrm{C}$ for $10 \mathrm{~min}$ (Mäntsälä \& Zalkin, 1976a). The supernatant was saturated with $\left(\mathrm{NH}_{4}\right)_{2} \mathrm{SO}_{4}$ to obtain a protein fraction precipitated between 37.5 and $49 \%$ saturation. The dissolved fraction $(22 \mathrm{ml})$ was applied to two tandem columns $(3 \mathrm{~cm} \times 100 \mathrm{~cm})$

Table 1. Effect of growth conditions on the activities of glutamate synthase and glutamate dehydrogenase

The samples were disrupted in a Raytheon DF 101 sonic oscillator in buffer $A$, centrifuged and the supernatants were assayed for glutamate synthase and dehydrogenase activities as previously described (Tempest et al., 1970; Miller \& Stadtman, 1972; Mäntsälä \& Zalkin, 1976a). Klett units were read by using filter no. 62 .

Activity (units/mg of protein)

$\begin{array}{crcc}\text { Medium } & \begin{array}{c}\text { Klett } \\ \text { units }\end{array} & \begin{array}{c}\text { Glutamate } \\ \text { synthase }\end{array} \begin{array}{c}\text { Glutamate } \\ \text { dehydrogenase }\end{array} \\ \begin{array}{crcc}\text { Casaminoacids(1\%) } \\ \text { (Difco Labora- }\end{array} & 75 & 0.04 & 0.002 \\ \text { tories, Detroit, } & 265 & 0.07 & 0.001 \\ \text { MI, U.S.A.) } & & 0.06 & 0.001 \\ \text { Glucose (20mM)+ } & 61 & 0.05 & 0.014 \\ \text { glutamate(10mM) } & 148 & 0.09 & 0.028 \\ & 196 & 0.08 & 0.035 \\ \text { Glucose (20mM)+ } & 56 & 0.03 & 0.014 \\ \text { lysine (10mM) } & 121 & 0.06 & 0.026 \\ & 173 & 0.07 & 0.023 \\ \text { Glucose (20mM)+ } & 60 & 0.04 & 0.042 \\ \mathrm{NH}_{4} \mathrm{Cl}(100 \mathrm{~mm}) & 139 & 0.06 & 0.147 \\ & 187 & 0.07 & 0.062 \\ \text { Glucose (20mM)+ } & 41 & 0.09 & 0.018 \\ \mathrm{NH}_{4} \mathrm{Cl}(3 \mathrm{~mm}) & 89 & 0.11 & 0.073 \\ & 111 & 0.13 & 0.069\end{array}$

Vol. 173 containing Ultrogel AcA 22. Protein was eluted with buffer B. The activities of interest were eluted in two regions. The pooled fractions of glutaminedependent glutamate synthase activity and of dehydrogenase activity were applied separately to a column $(1.5 \mathrm{~cm} \times 25 \mathrm{~cm})$ packed with DEAESephadex A-50. The proteins were eluted with a linear gradient of $0.1-0.7 \mathrm{M}-\mathrm{KCl}$ in buffer $\mathrm{B}$. The pooled fractions were concentrated by ultrafiltration with an Amicon PM 30 membrane. The dialysed fractions were applied to a column $(1.5 \mathrm{~cm} \times 8 \mathrm{~cm})$ of hydroxyapatite. Elution was carried out with a linear 5-200mm-potassium phosphate gradient, pH7.0. The pooled fractions of highest activity were concentrated as above and the final purification of the dehydrogenase was obtained by using preparative polyacrylamide-gel electrophoresis. The equipment supplied by Stålproducter, Uppsala, Sweden, was used and the run was carried out at $4^{\circ} \mathrm{C}$. About $16 \mathrm{mg}$ of protein was loaded on the column. Fig. 1 shows the elution profile of glutamate dehydrogenase. The activity was associated with the protein peak emerging at $95 \mathrm{ml}$ of washing buffer (25 mM-asparagine/19mm-Tris, pH8.5; Miller \& Stadtman, 1972). The gel $(1 \mathrm{~cm} \times 15 \mathrm{~cm})$ contained $5 \%(\mathrm{w} / \mathrm{v})$ acrylamide, was run at $10 \mathrm{~mA}$ and eluted with washing buffer at $0.5 \mathrm{ml} / \mathrm{min}$. The most active fractions were pooled and concentrated as above.

The overall yields were 30.5 and $23 \%$ and specific activities 23.8 and 45.0 units $/ \mathrm{mg}$ of protein in glutamate synthase and glutamate dehydrogenase respectively.

\section{Enzyme purity}

Homogeneity of the two enzymes was established by polyacrylamide-gel electrophoresis at $\mathrm{pH} 8.5, \mathrm{SDS} /$

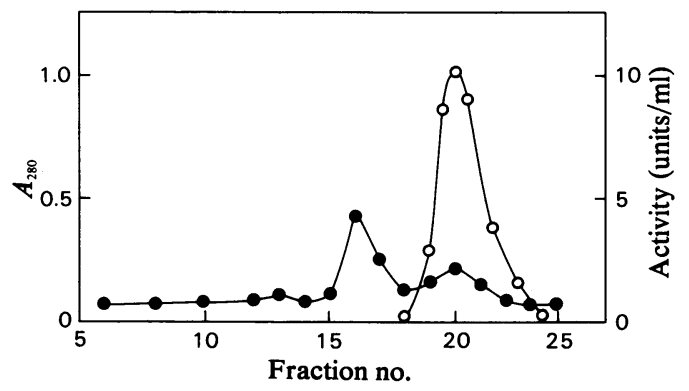

Fig. 1. Purification of glutamate dehydrogenase on preparative polyacrylamide-gel electrophoresis

The conditions for preparation and electrophoresis were described in the text. Electrophoresis was carried out at $\mathrm{pH} 8.5$ for $9 \mathrm{~h}$ by using $25 \mathrm{~mm}$-asparagine $/ 19 \mathrm{~mm}$ Tris buffer. Fractions $(5 \mathrm{ml})$ were collected and assayed for glutamate dehydrogenase activity. Symbols: $\bullet$, protein; $\bigcirc$, glutamate dehydrogenase activity. 


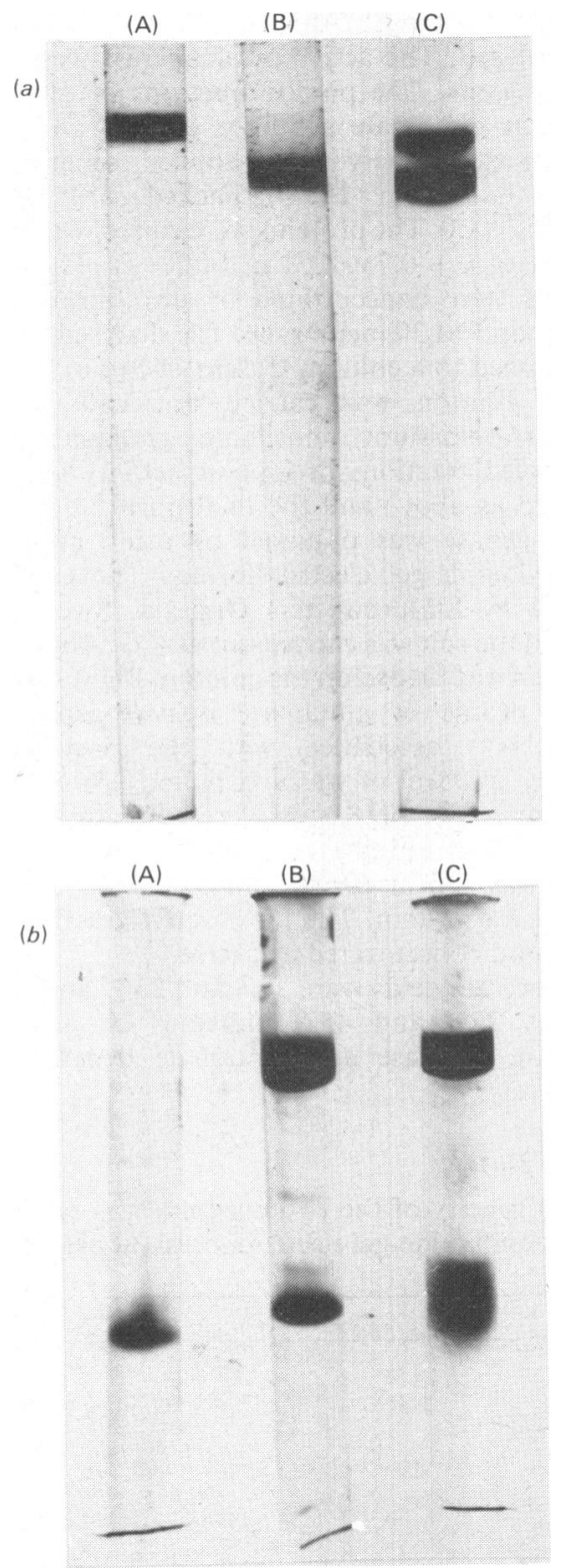

Fig. 2. Polyacrylamide gels electrophoresed (a) at pH8.5 and $(b)$ in the presence of SDS at $\mathrm{pH} 7.1$

(A) With $26 \mu$ g of glutamate dehydrogenase; (B) with $44 \mu \mathrm{g}$ of glutamate synthase; (C) with $33 \mu \mathrm{g}$ of glutamate synthase $+18 \mu \mathrm{g}$ of glutamate dehydrogenase.

polyacrylamide-gel electrophoresis at pH7.1 (Fig. 2) and sucrose-density-gradient ultracentrifugation experiments as described by Martin \& Ames (1961). The enzymes showed the same electrophoretic mobility as the enzymes from $E$. coli (Mäntsälä \&
Table 2. Amino acid composition of glutamate synthase and glutamate dehydrogenase from $B$. megaterium

Samples (about $0.3 \mathrm{mg}$ of protein) were hydrolysed in evacuated glass tubes at $110^{\circ} \mathrm{C}$ for $24 \mathrm{~h}$ with $6 \mathrm{M}-\mathrm{HCl}$ containing $10 \mu \mathrm{l}$ of ethylene glycol. After hydrolysis the samples were evaporated in vacuum and analysed in a Perkin-Elmer KLA-5 amino acid analyser. Enzyme activities were calculated for $24 \mathrm{~h}$ hydrolysates (average of two determinations).

Amino acid content

Glutamate synthase Glutamate dehydrogen( $\mathrm{mol} / \mathrm{mol}$ of enzyme ase $(\mathrm{mol} / \mathrm{mol}$ of enzyme of mol.wt. 210000) of mol.wt. 47000)

$\begin{array}{lrc}\text { Tyr } & 35.2 & 8.1 \\ \text { Phe } & 58.7 & 19.0 \\ \text { Lys } & 71.9 & 16.9 \\ \text { His } & 33.4 & 12.6 \\ \text { Arg } & 99.5 & 19.4 \\ \text { Asp } & 175.3 & 34.1 \\ \text { Glu } & 176.7 & 42.1 \\ \text { Thr } & 86.4 & 21.3 \\ \text { Ser } & 81.6 & 22.9 \\ \text { Pro } & 71.3 & 16.2 \\ \text { Ala } & 156.4 & 46.1 \\ \text { Gly } & 162.3 & 48.6 \\ \text { Val } & 106.2 & 29.2 \\ \text { Met } & 34.2 & 12.3 \\ \text { Ile } & 74.0 & 17.4 \\ \text { Leu } & 166.9 & 38.8 \\ \text { Cysteic acid } & 16.7 & 6.2\end{array}$

Zalkin, 1976b). Sucrose gradients (5-20\%) were prepared in the presence of buffer B. Samples $(1.4 \mathrm{mg}$ of glutamate synthase and $0.45 \mathrm{mg}$ of glutamate dehydrogenase) in $0.2 \mathrm{ml}$ of buffer B layered on $19.8 \mathrm{ml}$ gradients were centrifuged as described in the Materials and Methods section. Only two peaks of protein were detected after protein and enzyme determinations, corresponding to glutamate synthase and dehydrogenase activities.

\section{Amino acid composition}

The amino acid analyses of purified glutamate synthase and glutamate dehydrogenase are presented in Table 2.

\section{Kinetic and molecular properties}

Kinetic studies with the purified enzymes revealed that both enzymes are highly specific for NADPH. In the standard assay, NADH supported about 0.1 and $2.3 \%$ of the NADPH activity with glutamate synthase and glutamate dehydrogenase respectively. Table 3 summarizes some molecular and enzymic properties of the purified enzymes.

Two methods were used to determine the subunit structure of glutamate synthase. In one method, the 
colour intensities of the small and the large subunit of the SDS-treated glutamate synthase after electrophoresis and staining with Coomassie Blue were compared. After densitometer tracing, the ratio of relative areas $1.00 / 2.70$ (calculated $1.00 / 2.58$ ) and the molecular weights of 840000 for the native enzyme, 142000 for the large subunit and 55000 for the small subunit (Table 3 ) suggest an $\alpha_{4} \beta_{4}$ structure for the native enzyme. In the other method, crosslinking of the polypeptides was investigated (Fig. 3), which also suggests an $\alpha_{4} \beta_{4}$ structure, since the estimated molecular weight of the cross-linked adduct is about 180000 . After incubation for $1 \mathrm{~h}$ the most dominating combination was a protomeric $\alpha \beta$ structure, indicating that the small and the large polypeptide are tightly linked to each other in the native enzyme. Longer incubation time increased the

Table 3. Properties of glutamate synthase and glutamate dehydrogenase

The mean values of the molecular weights were calculated from the results of three runs. The apparent $K_{\mathrm{m}}$ and $V_{\max }$. values were calculated from the double-reciprocal plots. Assay mixtures in $50 \mathrm{~mm}-$ Hepes buffer (potassium salt) at pH7.5 and 8.0 for glutamate synthase and glutamate dehydrogenase respectively contained $1 \mathrm{mM}$-EDTA, $3.4 \mu \mathrm{g}$ of enzyme and variable amounts of: $\mathrm{NADP}^{+}$(with $4 \mathrm{~mm}-2-$ oxoglutarate and $100 \mathrm{~mm}-\mathrm{NH}_{4} \mathrm{Cl}$ ); NADPH (with $2 \mathrm{~mm}$ - or $4 \mathrm{~mm}$-2-oxoglutarate and $2 \mathrm{~mm}$-L-glutamine or $100 \mathrm{~mm}-\mathrm{NH}_{4} \mathrm{Cl}$ ); 2-oxoglutarate (with $0.1 \mathrm{~mm}$ -

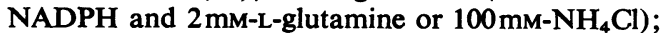
glutamate (with $0.1 \mathrm{mM}-\mathrm{NADPH}^{+}$); $\mathrm{NH}_{4} \mathrm{Cl}$ (with 4 mm-2-oxoglutarate, 0.1 mm-NADPH) (Miller \& Stadtman, 1972; Mäntsälä \& Zalkin, 1976b).

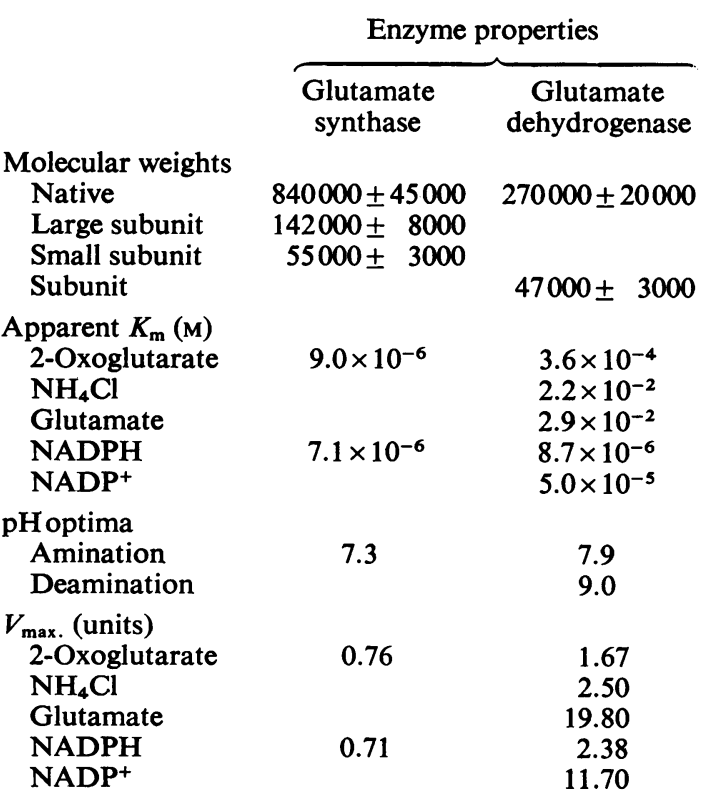

number of high polymeric forms. A similar result was obtained when the highly purified glutamate synthase from $E$. coli was treated with dimethyl suberimidate.

Amidination of glutamate synthase with dimethyl suberimidate inactivated glutamine-dependent activity, but increased $\mathrm{NH}_{3}$-dependent activity (Fig. 4). Inactivation of glutamine-dependent activity did not

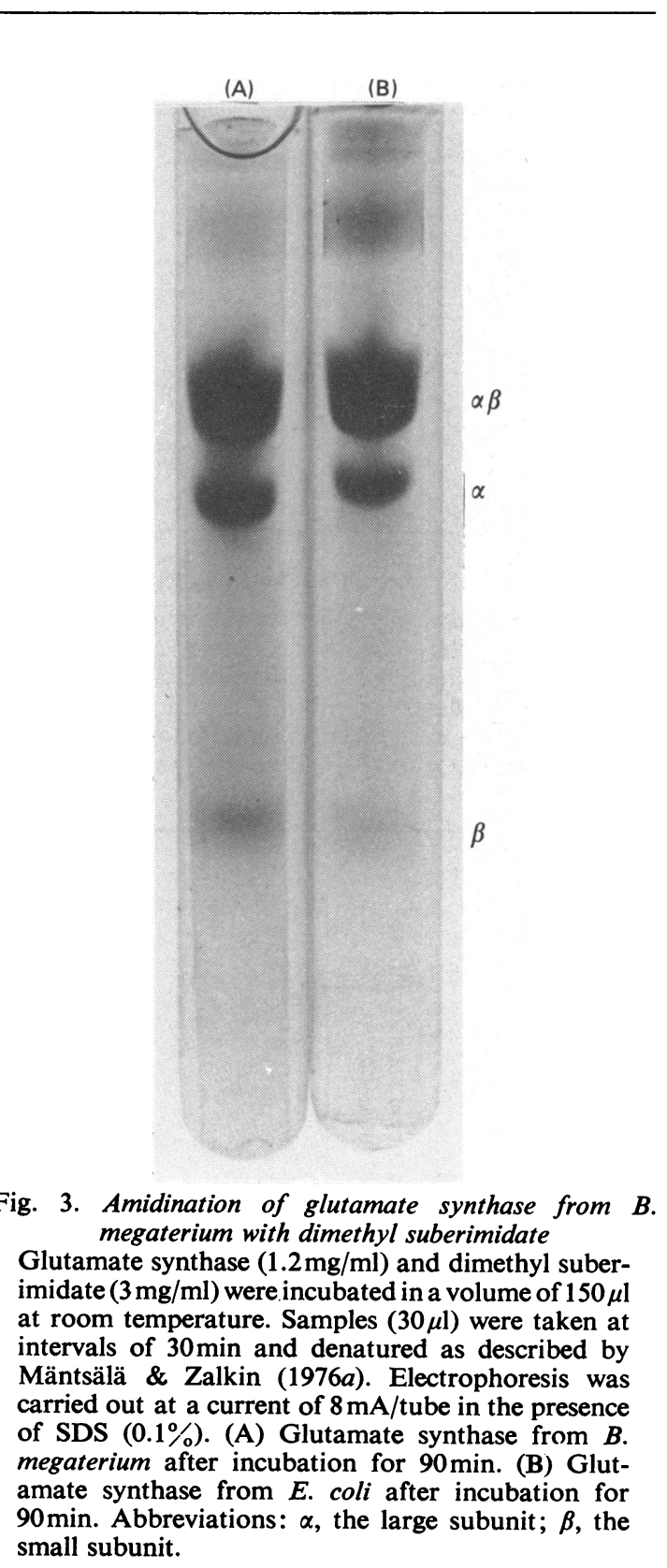

Vol. 173 
follow formation of the protomer. About $90 \%$ crosslinking resulted in $50 \%$ inactivation of the enzyme. The same treatment increased $\mathrm{NH}_{3}$-dependent activity about 1.5 -fold. Although we conclude that a structural change is responsible for the decrease in glutamine-dependent activity, it is not excluded that

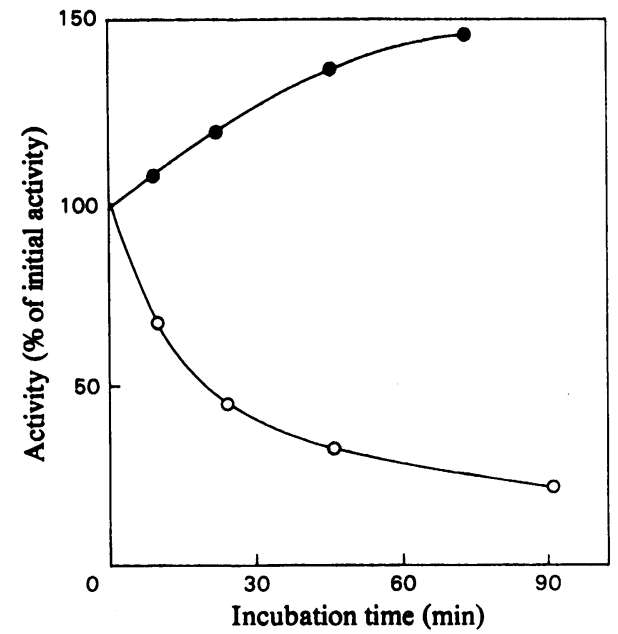

Fig. 4. Effect of dimethyl suberimidate on glutamine- and $\mathrm{NH}_{3}$-dependent activities

Glutamate synthase and dimethyl suberimidate were incubated as described in the legend to Fig. 3. Samples $(10 \mu \mathrm{l})$ were taken as indicated and assayed for glutamine- $(\mathrm{O})$ and $\mathrm{NH}_{3}$-dependent $(\bullet)$ activities. dimethyl suberimidate inactivates the enzyme reacting with a residue located at or close to the active site.

Enhancement of $\mathrm{NH}_{3}$-dependent activity of apo(glutamate synthase)

Purified glutamate synthase from $B$. megaterium exhibited $\mathrm{NH}_{3}$-dependent activity similar to the enzymes from $E$. coli (Mäntsälä \& Zalkin, 1976b) and Aerobacter aerogenes (Trotta et al., 1974; Geary \& Meister, 1977). The activity was normally $2-4 \%$ of the glutamine-dependent activity. Treatment with $0.2 \mathrm{M}$-sodium acetate buffer, pH4.6 (Mäntsälä \& Zalkin, 1976a), released non-haem iron and flavin into the supernatant solution and precipitated the apoenzyme. The supernatant did not contain any protein, but $7.1 \mathrm{nmol}$ of total flavin nucleotide (both FAD and FMN)/mg of native protein was released during this treatment. After neutralization the apoenzyme remained insoluble, but $\mathrm{NH}_{3}$-dependent activity increased about 4-fold. A similar stimulation of $\mathrm{NH}_{3}$-dependent activity during treatment at pH4.6 was also found when activity measurements were made before the neutralization of the precipitated apoenzyme.

Glutamine-dependent glutamate synthase and glutamate dehydrogenase activities decreased during the same treatment (Fig. 5). In some experiments glutamine-dependent activity disappeared immediately at $\mathrm{pH} 4.6$, though the activity measurements were made either before or after neutralization of the precipitated enzyme. However, the inactivation was reversible and activity appeared slowly

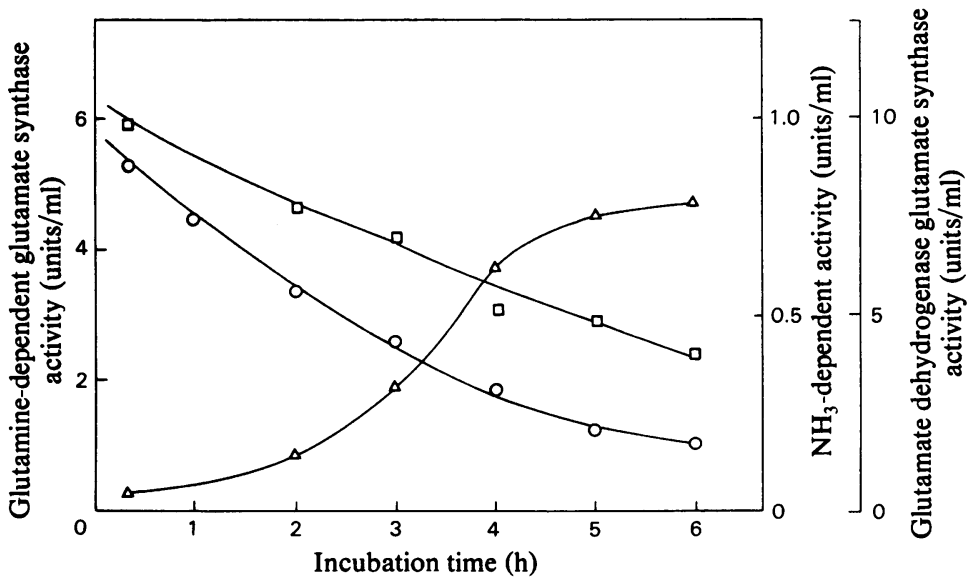

Fig. 5. Effect of treatment at pH4.6 on enzyme activities

Glutamate synthase $(220 \mu \mathrm{g})$ and glutamate dehydrogenase $(90 \mu \mathrm{g})$ were incubated at room temperature $\left(25^{\circ} \mathrm{C}\right)$ in a mixture containing $0.1 \mathrm{M}-\mathrm{KCl}$ and $0.2 \mathrm{M}$-potassium acetate, pH4.6 (total volume of reaction mixture $0.1 \mathrm{ml}$ ). Samples $(0.01 \mathrm{ml})$ were removed and assayed for enzyme activities. Symbols: $O$, glutamine-dependent glutamate synthase; $\Delta, \mathrm{NH}_{3}$-dependent glutamate synthase; $\square$, glutamate dehydrogenase. 
within $30-60 \mathrm{~min}$. After this reactivation, slow inactivation of glutamine-dependent activity and stimulation of $\mathrm{NH}_{3}$-dependent activity were similar to those shown in Fig. 5. Similar to many other glutamine amidotransferases, glutamate synthase exhibits glutaminase activity. This reaction is a partial one that hydrolyses the amido group of glutamine, uncoupled from amination. Glutaminase activity did not decrease equally with glutaminedependent activity. Glutaminase activity decreased from $0.83 \mathrm{unit} / \mathrm{mg}$ (native enzyme) to $0.57 \mathrm{unit} / \mathrm{mg}$ (apoenzyme). To determine the effect of pH4.6 treatment on the incorporation of $\left[{ }^{14} \mathrm{C}\right]$ carbambylmethyl, samples were removed at selected times and incubated with iodo[ $\left[1-{ }^{14} \mathrm{C}\right]$ acetamide. After incubation the samples were passed through a Sephadex column, dialysed and counted for radioactivity. Incorporation of $\left[{ }^{14} \mathrm{C}\right]$ carbamoylmethyl decreased during treatment at $\mathrm{pH} 4.6$ from $1.45 \mathrm{~mol} /$ $\mathrm{mol}$ of enzyme to $0.97 \mathrm{~mol} / \mathrm{mol}$ of enzyme.

\section{Discussion}

With an excess of nitrogen, even as glutamate, a carbon-limited culture of $B$. licheniformis synthesizes glutamate dehydrogenase. However, the addition of glutamate to the cells growing in excess of glucose/ $\mathrm{NH}_{3}$ medium results in strong repression of synthesis of this enzyme (Meers \& Pedersen, 1971). Similarly the cells grown on media containing glutamate or lysine as the nitrogen source exhibited very low glutamate dehydrogenase activities compared with the activities obtained in cells grown on glucose $/ \mathrm{NH}_{3}$ medium (Table 1 ). Further, the specific activities of glutamate dehydrogenase were extremely low when $B$. megaterium was grown on casamino acids. These results suggest that the enzymes have a physiological significance similar to that found in many other bacteria; under conditions of low concentrations of $\mathrm{NH}_{3}$ glutamate synthase functions, and the concentrations of glutamate dehydrogenase are very low, whereas in the presence of high concentrations of $\mathrm{NH}_{3}$ glutamate dehydrogenase provides the main route for $\mathrm{NH}_{3}$ assimilation.

The molecular structure and properties of glutamate synthase and glutamate dehydrogenase from bacilli are not well established. It is known that glutamate dehydrogenases from different sources vary greatly in their molecular structure. The molecular weight of glutamate dehydrogenase from a thermophilic bacillus is approx. $2 \times 10^{6}$, which is about 6-7 times greater than the molecular weight of the enzyme from many other bacterial sources. The molecular weight and physical properties of glutamate dehydrogenase from $B$. megaterium were similar to those of many bacterial glutamate dehydrogenases (Coulton \& Kapoor, 1973; Johnson \& Westlake, 1972; Veronese et al., 1975;
Sakamoto et al., 1975), whereas those of glutamate synthase were similar to the enzyme from $E$. coli (Mäntsälä \& Zalkin, 1976a) and $A$. aeragenes (Trotta et al., 1974). Glutamate synthase from $E$. coli (Mäntsälä \& Zalkin, 1976a) and $A$. aerogenes (Trotta et al., 1974; Geary \& Meister, 1977) exhibits glutamine- and $\mathrm{NH}_{3}$-dependent activities. However, as in the case of carbamoyl phosphate synthetase from mammalian (Abrams \& Bentley, 1959) and avian (Lagerkvist, 1958) tissues, glutamate synthase from bacterial sources exhibits higher activity with glutamine than with $\mathrm{NH}_{4} \mathrm{Cl}$ as the amino donor. It seems very unlikely that $\mathrm{NH}_{3}$ utilization by glutamate synthase is an artefact due to contamination by glutamate dehydrogenase, because no evidence of contamination was detected in SDS or discontinuous polyacrylamide gels and because the $\mathrm{NH}_{3}$ activity of the enzyme increased about 4-fold during treatment at $\mathrm{pH} 4.6$, whereas glutamate dehydrogenase was inactivated during this treatment. When glutamate synthase was purified from Klebsiella aerogenes MK 270 (this mutant contains only about $1 \% \mathrm{NH}_{3}$-dependent activity), $\mathrm{NH}_{3}$ dependent activity was associated with glutaminedependent activity throughout the purification procedure (results not shown). The overall results favour the conclusion that the quaternary structure of glutamate synthase has a functional site for glutamine, but that a site for $\mathrm{NH}_{3}$ is somehow blocked. After acid treatment apo(glutamate synthase) has a functional site for $\mathrm{NH}_{3}$, but non-haem iron and flavin, which obviously are required for function of glutamine site, are released. The fact that the incorporation of $\left[{ }^{14} \mathrm{C}\right]$ carbamoylmethyl and glutamine-dependent activity have not been decreased equally indicates that flavin is linked only to glutamine-dependent glutamate synthase. The isolation of $S$-carboxymethylcysteine after alkylation with iodo$\left[1-{ }^{14} \mathrm{C}\right]$ acetamide provided evidence that a cysteine residue may have an essential role in the binding of glutamine in glutamate synthase from $E$. coli (Mäntsälä \& Zalkin, 1976a). On the basis of experiments with alkylating and thiol (results not shown) reagents we suggest that a cysteine residue could be essential also to the binding of $\left[{ }^{14} \mathrm{C}\right]$ carbamoylmethyl in glutamate synthase from $B$. megaterium. Nearly $90 \%$ inactivation of glutamine-dependent glutamate synthase was found within $5 \mathrm{~min}$ in the presence of $50 \mu \mathrm{M}-p$-mercuribenzoate. Glutamine (20mM) provided substantial protection $(60-70 \%)$ against inactivation. During treatment at $\mathrm{pH} 4.6$ the site for glutamine is partially destroyed and the incorporation of $\left[{ }^{14} \mathrm{C}\right]$ carbamoylmethyl and glutaminase activity somewhat decreased. Mäntsälä \& Zalkin $(1976 a, b)$ and Geary \& Meister (1977) have shown that the mechanism of the glutamine-mediated reductive amination is fundamentally different from that of the $\mathrm{NH}_{3}$-mediated reductive amination. 


\section{References}

Abrams, R. \& Bentley, M. (1959) Arch. Biochem. Biophys. 79, 91-110

Baker, J., Jeng, I. \& Barker, H. A. (1972) J. Biol. Chem. 247, 7724-7734

Burch, H. B., Bessey, O. A. \& Lowry, O. H. (1948) J. Biol. Chem. 175, 457-470

Coulton, J. W. \& Kapoor, M. (1973) Can. J. Microbiol. 19, 427-438

Curthoys, N. P. \& Weiss, R. F. (1974) J. Biol. Chem. 249, 3262-3266

Davies, G. E. \& Stark, G. R. (1970) Proc. Natl. Acad. Sci. U.S.A. 66, 651-656

Elmerich, C. \& Aubert, J.-P. (1971) Biochem. Biophys. Res. Commun. 42, 371-376

Epstein, I. \& Grossowics, N. (1975) J. Bacteriol. 122, 1257-1264

Geary, L. E. \& Meister, A. (1977) J. Biol. Chem. 252, 3501-3508

Johnson, W. M. \& Westlake, D. W. S. (1972) Can. J. Microbiol. 18, 881-892

Lagerkvist, U. (1958) J. Biol. Chem. 233, 143-149

Lowry, O. H., Rosebrough, N. J., Farr, A. L. \& Randall, R. J. (1951) J. Biol. Chem. 193, 265-275

Mäntsälä, P. \& Zalkin, H: (1976a) J. Biol. Chem. 251, 3294-3299
Mäntsälä, P. \& Zalkin, H. (1976b) J. Biol. Chem. 251, 3300-3305

Martin, R. G. \& Ames, B. N. (1961) J. Biol. Chem. 236, 1372-1379

McElvain, S. M. \& Schroeder, J. P. (1949) J. Am. Chem. Soc. 71, 40-46

Meers, J. L. \& Pedersen, L. K. (1971) J. Gen. Microbiol. 70, 277-286

Meers, J. L., Tempest, D. W. \& Brown, C. M. (1971) J. Gen. Microbiol. 64, 187-194

Miller, R. E. \& Stadtman, E. R. (1972) J. Biol. Chem. 247, 7407-7419

Nagano, H., Zalkin, H. \& Henderson, J. (1970) J. Biol. Chem. 245, 3810-3820

Phibbs, P. V. \& Bernlohr, R. W. (1971) J. Bacteriol. 106, 375-385

Sakamoto, N., Kotre, A. M. \& Savageau, M. A. (1975) J. Bacteriol. 124, 775-783

Shapiro, A. L., Vinuela, E. \& Maizel, J. V., Jr. (1967) Biochem. Biophys. Res. Commun. 28, 815-820

Tempest, D. W., Meers, J. L. \& Brown, C. M. (1970) Biochem. J. 117, 405-407

Trotta, P. P., Burt, M. E., Haschemeyer, R. H. \& Meister, A. (1974) Proc. Natl. Acad. Sci. U.S.A. 68, 2599-2603

Veronese, F. M., Boccu, E. \& Conventi, L. (1975) Biochim. Biophys. Acta 377, 217-228

Weber, K. \& Osborn, M. (1969) J. Biol. Chem. 244, 4406-4412 